\title{
The Comparison of Evaluative That Clauses in Turkish L2 Novice and Expert Writers' Abstracts
}

\author{
Türkçe Anadilli Deneyimsiz ve Uzman Yazarların Makale Özetlerinde Tutum \\ Belirleyici Ki-Cümleciklerinin Karşılaştırılması
}

\author{
Hatice Altun \\ Öğr. Gör. Pamukkale Üniversitesi \\ Yabancı Diller Yüksekokulu, Yabancı Diller Anabilim Dalı, Denizli / Türkiye \\ e-posta haticealtun@gmail.com \\ orcid 0000-0003-4096-4018 \\ doi $\quad 10.54316 /$ dilarastirmalari.1012755
}

Atıf

Citation

Altun, Hatice (2021). The Comparison of Evaluative That Clauses in Turkish L2 Novice and Expert Writers' Abstracts.

Dil Araştırmaları, 29: 99-114.

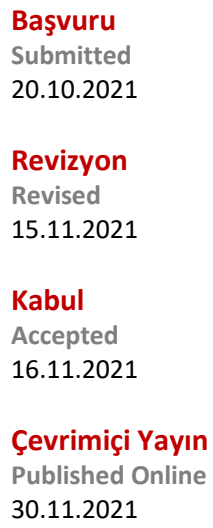

öz

Yazarların nasıl bir yazarlık tutumu benimsedikleri ve okuyucularıla nasıl bağlantı kurdukları literatürde ilgi görmüştür ve artık birçok ESP müfredatının da önemli bir parçasıdır. Hyland ve Tse'nin (2005b) 'değerlendirici that' olarak adlandırdıkları yapı, literatürde kişilerarası bir özellik olarak yeterince çalışılmamıştır. Bu form, bir üst cümlenin içine tamamlayıcı bir alt cümle yerleştirerek, yazarların bir duruş takınmasına ve kendilerinin veya başkalarının çalışmalarını açıkça değerlendirmelerine olanak tanır. Uygulamalı dilbilim alanında öğrenci ve uzman yazarların hazırladığı özetlerde bu yapının kullanımını, yazara ait geri bildirim ve değerlendirme vermenin önemli bir yolu olarak görülür. $\mathrm{Bu}$ çalışmada, ABD'de L2 Türk yüksek lisans ve doktora öğrencileri tarafindan yazılan tezlerden ve uygulamalı bir dilbilim dergisinde yayınlanmış araştırma çalışmalarından elde edilen 110 özet kısmından oluşan iki derlem incelenmiştir. Bu özetlerde değerlendirici that ifadesinin yetkin akademisyenlere göre deneyimsiz Türk yazarlar tarafindan daha az kullanıldığı gözlemlenmiştir. Sonuçlar, iki grubun yapıyı çoğunlukla benzer olarak kullandığını ama deneyimsiz yazarların yapıyı nasıl farklılaşarak kullandığını göstermiştir. Çalışmanın sonuçları, yazarların neyi değerlendirmeye karar verdiklerine, benimsedikleri bakış açılarına, duruşu yükledikleri kaynağa ve yargılarını nasıl sunduklarına bakarak, uzman ve deneyimsiz yazarların yazarlık tutumu hakkında ipuçları vermektedir.

Anahtar Kelimeler: değerlendirici bu 'that', İngilizce yazan deneyimsiz Türk yazarlar, yazar duruşu, gömülü ki-cümleler

\section{ABSTRACT}

How authors adopt a stance and connect with their readers has gotten a lot of attention in the literature and is now a significant part of many ESP 
courses. What Hyland and Tse (2005b) call 'evaluative that' is a primarily underappreciated interpersonal trait. By placing a complement clause within a superordinate sentence, this form allows authors to build authorial stance and explicitly evaluate their own or others' work. It is an important way of giving authorial feedback and assessment when comparing the use of the structure in student and expert abstracts in applied linguistics. The current work explores two corpora comprising 40 abstracts from masters' theses and dissertations by Turkish L2 graduate students in the U.S., and 70 abstracts by published research studies in two applied linguistics journals. It was discovered that evaluative that is less commonly used in these abstracts by the novice Turkish L2 graduate students than the published scholars. Although both groups used the structure similarly to a large extent, novice writers presented some peculiar traits concerning the specific uses of the structure. The results of the study give hints about the authorial voice of the expert and L2 novice writers by looking at what writers decided to assess, the viewpoints they adopted, the source they ascribed the stance to, and how they presented their judgments.

Keywords: evaluative that, novice L2 Turkish writers, authorial stance, Turkish paratactic assertions through embedded ki-clauses

\section{Introduction}

The significance of authorial stance and metadiscourse in academic writing is now well recognized, and it has sparked ample research in recent years (Biber 2006; Hunston 2000; Hunston - Thompson, 2001; Hyland 2005; Hyland - Jiang, 2018). Biber and Finegan (1988) describe authorial stance as the grammatical and lexical articulation of attitudes, sentiments, judgments, or commitment to a message's propositional content. Stance is pivotal in negotiating the arguments while allowing authors to establish voice and convince their readers (Hyland - Jiang 2018). Biber and Finegan (1989) report that linguistic expression of stance has been studied mainly under two titles: evidentiality and affect. Evidentiality is the indication of the reliability of the information and evidence for the given information, and thus it is the verificational sign of knowledge (Chafe 1986). On the other hand, the latter refers to the personal dispositions and feelings of the author with regard to the shared information (Ochs - Schieffelin 1989). Evidentiality and affect have been studied in English and many western and non-western languages such as Turkish and Japanese (Aikhenvald 2018; Arslan - De Kok - Bastiaanse 2017; Diewald - Smirnova 2010; Gençer Baloğlu 2020; Yang - Narrog 2018).

Under these two main titles, evidentiality and affect, various linguistic features of the texts have been explored to show the authors' voice choices, such as reporting verbs, directives, and tense (Tarone 1998; Thompson 1991). From among the many adverbial, adjectival, verbal, and modal stance markers investigated by Biber (2006) and Biber and Finegan (1989), Hyland and Tse (2005a, 2005b) focus on verb+that constructions as less studied markers of stance. These 'evaluative that-clauses' have received the slightest notice to explore the interpersonal features of the written texts and the influence of L1 transfer. Biber and Reppen (1998) found out that the use of that-clauses changes depending on the L1 background of the learners. The novice DiL 
corpus that will be analyzed in the current paper comprises the abstracts written by Turkish L1 authors. In that sense, the article may contribute to exploring the influence of 'use transfer' (Wu 1995), that is, the transfer of favored patterns of use in an L1 to an L2. Turkish has a similar evaluative construction to English, that is, 'embedded kiclauses,' which are less used in the academic genre but often used in spoken registers and some literary genres (Göksel - Kerslake 2005; Kesici 2013). In scholarly texts, in Turkish, however, an almost invisible tone of authorial stance is expressed through passive constructions and some evidential suffixes such as $-m I$ ş/- $(y) m I$ ş (Gençer Baloğlu, 2020), or the neutral past tense marker $-D I$, and additionally, the epistemic suffix-DIr is used exuberantly for the empirical evidence (Aksu-Koç 2016).

In English, 'evaluative that-clauses' regulated by verbs are commonly exploited to project authors' thoughts, feelings, attitudes (Hyland - Tse 2005a, 2005b). Evaluative that-clauses are "grammatical structures in which a complement clause is embedded in a host super-ordinate clause to complete its construction and to project the writer's attitudes or ideas" (Hyland - Tse 2005b: 124); e.g., 'We argue that academic writing should be more flexible.' is a complement clause embedded in the super-ordinate clause 'we argue.' In that sense, 'evaluative that-clauses' are powerful expressions that reveal subjective evaluations in academic texts because they allow the writer to add attitudinal meaning and stance to the discussion. Evaluative clauses provide authors with more options to show their stance than using a lexical item or modal verb.

Research has increased to find out how academic writers have embedded their voice in their texts to evaluate their findings and build a relationship with their readers (Matsuda - Tardy 2006). Due to the subtle balance between neutrality and visibility, researchers use voice and stance in various ways. However, EAP (English for academic purposes) materials strictly guide the students to adopt an objective and impersonal but informational tone (Hyland 2002; Hyland - Tse 2012). The student writers are expected to disguise their authorial identity and deal with facts only (Hyland - Tse 2005b). Yet, expert writers are considered to contribute to the literature, and they have the liberty to present subjective interpretations and persuade the reader on their claims (Swales 2002). Additionally, several other studies have demonstrated that expert academic writers construct an authorial stance that reflects the epistemology and ideology in their disciplines and thus have signified the extent to which authorial stance is contained in disciplinarity (Charles 2006; Hyland - Tse 2005b). Student writers, on the other hand, may not be able to reflect the disciplinary ideology.

In the current paper, I likewise employ the model of evaluative that-clauses by Hyland and Tse (2005b) to conduct a contrastive study of evaluative-that clauses and their stance functions between the abstracts of (master-doctoral) theses and the abstracts of two journal articles (TESOL Quarterly and Applied Linguistics). In two corpora comprising 40 and 70 abstracts from dissertations-theses and published research papers, respectively, the frequencies, evaluative entities, stance, stance resources, and expressions were investigated. First, I describe the characteristics of evaluative that-clauses, then explain the method and compare the various uses of evaluative that-clauses in the two corpora. I will also discuss a possible negative transfer that might affect Turkish learners' expected lack of authorial voice based on the syntactical features of Turkish. 


\section{Review of Literature}

Evaluative that-clause refers to the phrases contained in the main clause that acts as a subordinate, describing the writers' own opinions and perspectives. Evaluative-that clause is considered evaluative in the sense that it is used with a range of different verbs such as suggest, believe, think, prove, and state, which all show personal judgment (Biber et al. 1999). For example,

- We prove that the method used was ...

- It was found out that the results of this study are in consistency with the...

- This analysis demonstrates that...

Or a noun such as reason, assumption, fact (Charles 2007; Jiang - Hyland 2015) and or an adjective like apparent, noteworthy (Biber 2006) can follow the clause, for example:

- The study was based on the assumption that ...

- ... there is no proof that the participants were...

- We are quite confident that the findings will be ...

- It is a well-known fact that languages have been evolving ...

- ...it is noteworthy that the increase in the use of the lexical structure...

Extraposition is a sort of evaluative structure in which the subject is shifted (extraposed) to a position following the original predicate and substituted by it as subject (Biber et al. 1999). Extraposition is often used in scholarly prose (Biber et al. 1999; Herriman 2000). It enables writers to express their comments at the end of the sentence by shifting complicated chunks to the end (Biber et al.1999). Hewings and Hewings (2002) also observed that 'anticipatory it' is another often exploited structure in academic writing. For example:

- It will ensure that the project results that remain accessible and used by others will be shared.

- ... it is vital that the results are visible and accessible...

However, these studies are limited to clauses with $i t$ in the subject position and neglect clauses with alternative subject possibilities. According to Hyland and Tse (2005b), the usage of evaluative that-clauses is fairly common in the abstracts of Hong Kong master's and Ph.D. theses, and authorial attitudes are more apparent in technical articles than in scientific, humanities texts. Charles (2006) also states that the key linguistic ways to denote writers' viewpoints are that-clauses followed by reporting verbs. According to Charles (2006) unless they are ascribed elsewhere, a writer is presumed to aver all of the propositions in the text and so assumes responsibility for their validity. When an attribution is made, a statement is credited to a source other than the writer, and accountability is taken by that entity or person. 
Hyland and Tse (2005a, b) see that-clauses as a single unit to express evaluative stance. These seemingly disparate patterns should be viewed as a unified and coherent rhetorical strategy, which allows the different uses to cohere around a fundamental meaning of attitude and judgment. The stances that can be taken by a writer are identified by Hyland and Tse (2005b) into four categories: the thing to be evaluated (evaluation object), the stance that will be taken towards the thing evaluated (evaluation stance), who will take charge of the evaluation (source of stance), and how is it going to be expressed (syntactic features). The theoretical basis for this study is Hyland and Tse's (2005b) categorization technique of evaluative that-clause. The categorization of that clause can be further explored through a detailed table prepared by Hyland and Tse (2005b, p.130).

\subsubsection{The evaluation object}

Hyland and Tse (2005b) observe that writers make four types of evaluations: assessments of their own results, evaluations of prior studies, statements of research study aim, and reviews of the theories utilized in the study. The study's research objective is more implicitly evaluative, and they state what they want to explore, provide a strategy for doing so, and assess something for relevance and worth.

\subsubsection{The evaluative stance}

The second type is the writers' attitude, which is expressed by a predicate (an adjective or a reporting verb) and an epistemic or attitudinal viewpoint. An attitudinal stance might transmit sentiments (likes and dislikes, hope, etc.) or obligations (what should be done); but an epistemic stance discloses a judgment of the proposition's correctness.

\subsubsection{The source of the evaluation}

Hyland and Tse (2005b) state that writers attribute the evaluation to three sources: it could either be a human source, like the authors themselves or the other researchers, second to an abstract entity, like the results or data, as the third one, to an unspecified formulator, obscuring the source of the evaluation by assigning it to a generic subject similar to 'it.'

\subsubsection{The evaluative expression}

The appraisal might be vocal or nonverbal, depending on the writer's preference. Nouns and adjectives are used in nonverbal forms. Hyland and Tse (2005b) divided the verbal forms under the following categories:

- Research acts, which reflect real-world experimental activities or actions (e.g., demonstrates, exhibit, expose)

- Discourse acts aimed at expressing research activities (e.g., investigate, observe, report)

- Cognitive acts are those that describe the mental processes of a researcher (e.g., hope, believe, advocate, assume) 
The interaction of these elements determines how authors want their studies to be perceived and guide the reception of readers about their arguments. These four usages are significant rhetorical choices at the intersection of grammar and lexis, indicating not just the authorial viewpoints of authors, as demonstrated by Charles (2007), but also the content they remark on and the voice they use to do so.

Despite rising academic interest in evaluation and stance in various disciplines (Charles 2006, 2007; Hyland - Tse, 2005b), few studies have looked at how these are influenced by the L1 background (Biber - Reppen 1998) and a specific discipline epistemology and ideology, i.e., applied linguistics. Taking my cue from Hyland and Tse's (2005a, b), I attempt to compare L2 Turkish novice writers' evaluative clauses with the expert writers in applied linguistics in two corpora. In order to make safe assumptions about the L1 influence on the use of evaluative that-clauses, we need to inform ourselves with the Turkish evaluative and stance-making lexical and syntactic linguistic devices. The following section will give a brief survey of Turkish embedded ki- clauses and other evidential markers.

\subsection{Turkish Embedded ki- Clauses and Other Evidential Markers for Evaluation and Stance}

Similar to that clauses in English, Turkish ki-clauses are embedded clauses that begin with the complementizer $k i$. Since the particle $k i$ was adopted into Turkish from Persian, $\mathrm{ki}$ - clauses have typically been thought to be subordinate clauses of the IndoEuropean style (Göksel - Kerslake 2005). Unlike native nominalized subordinate clauses, ki-clauses have SVO word order and certain other irregular surface qualities. For example:

Bu çalışmada belirtilmektedir $\boldsymbol{k i}$ [çokdillilik Türkiye'de yaygınlaşmıştır].

It is stated in this study that [multilingualism has become widespread in Turkey].

In Turkish, the ki-clause is not the most common kind of clause embedding. The nominalized subordinate clause is the most prevalent sort of embedded clause. Nominalized subordinate clauses are case marked. They occur with a genitive subject, show nominal agreement, and come before the matrix verb - in their default place following the typical Turkish SOV pattern:

$\mathrm{Bu}$ çalışma, çokdilliliğ-in (-GEN) Türkiye'de yaygınlaştığı-nו(-ACC) belirtmektedir.

This study states that multilingualism has become widespread in Turkey.

Kesici (2013) argues that subordination analysis of $k i$-clauses are not tenable and further argues that there is evidence that ki-clauses are assertions and, as such, autonomous statements with their own illocutionary power. The predicates that are non-assertive cannot precede a ki-clause. For example,

Bu uygulamayla anlaşılmıştır $\boldsymbol{k i}$ [dil öğretimi artık eskisi gibi olmayacak].

With this application, it has been understood that [language teaching will no longer be the same as before].

Despite their assertive nature, $k i$ - clauses are considered somewhat archaic expressions, and it is pretty rare to encounter $k i$-clauses in academic texts in Turkish. 
However, it is a prevalent usage in colloquial language. Therefore, it can be assumed that Turkish L2 novice writers are familiar with the structure so that they can quickly transfer it in English. Other evidential makers and neutral or epistemic suffixes are frequently used to show the source of information and present evaluation and stance. Usually, $-m I s ̧ /-(y) m I s$, the neutral past tense marker $-D I$, and additionally the epistemic suffix $-D I r$ are used to report empirical evidence. Y1ldiz and Aksan (2013) observed that the most frequently used verbs in Turkish are as follows: görül-mekte dir, göster-mekte-dir, bulun-muştur, gerek-mekte-dir, bulun-makta-dır, görül-müştür, belirlen-miş-tir, söylen-ebilir, gerek-ir. It can be observed that most of the verbs are written in progressive modalities followed by evidentials. Turkish authors adopt a low stance in academic prose (Çakır 2016; Can - Yuvayapan 2018; Çandarlı 2012; Çandarlı - Bayyurt - Martı 2015; Işık-Taş 2018) and often use a passive language to attribute the source of evaluation, concealing their agentive role. In that sense, Turkish L2 authors' implicit way of writing reflects the high-context communication society they come from, and they differ from the native English speakers' explicit and agentive argumentative way.

The current study aims to provide answers to the following questions:

1) Is the frequency of that sentence in the Corpus of English Abstracts of Theses compatible with the Corpus of Applied Linguistics Journal Abstracts?

2) How do novice Turkish L2 writers construct their authorial voice using evaluative that-clause?

\section{Methodology}

Two corpora were compiled for this study. In total, 40 abstracts of masters' and doctoral theses written in L2 by Turkish students and submitted to various universities in the US were extracted from the ProQuest database, and they were used to form the Corpus of English Abstracts of Theses and Dissertations (from now on referred to as CEAT or novice corpus). The abstracts were chosen from the applied linguistics department only in order to study a specific major. Meanwhile, 70 abstracts in applied linguistics journals were extracted from TESOL Quarterly and Applied Linguistics Journals. These journals are considered to be some of the most prestigious ones in the field. The corpus was named the Corpus of Applied Linguistics Journal Abstracts (hereinafter referred to CALJA or expert corpus). Because of their reasonable length and concise presentation of reasoning, I opted to explore abstracts, and Hyland and Tse (2005b) regard abstracts as a critical genre as well as a potentially rich source of evaluative that-clauses. However, I needed to keep in mind that article and dissertation abstracts are at different lengths, with the latter being lengthier. To attain the number of words in the journal article corpus, I picked a smaller number of theses and dissertation abstracts.

Sources in both corpora were chosen from among unpublished theses and dissertations written by Turkish L2 writers and articles published in journals between 2012 and 2020 to assure the efficacy of the two corpora. The data was retrieved using 
Hyland and Tse's (2005b) concept of evaluative that-clause. After collecting the abstracts in a word document, I pasted them as a nano file. In order to get rid of the spaces in the nano file, I used a Perl code, which ensured proper lining without unnecessary breaks.

To find all that-clauses, E-grep was utilized initially. I went over the concordance lines many times on my own, looking at that-clauses in their textual settings to observe how authors employed the structure and infer a classification pattern for the roles thatclauses performed. I then manually filtered out those that didn't have the features of an evaluative that-clause, such as relative clauses like that, so that, and demonstrative adjectives like that. Following the screening, I observed that a significant percentage of 'that's in the novice corpus were relative clause pronouns. However, this aspect of the novice corpus is beyond the scope of this study, it is not going to be studied in the current paper. I also excluded the omitted that cases. Finally, I grouped all the instances of evaluative-that clause into four categories mentioned in the literature review section. Since the corpus data is not large enough, only descriptive statistics is used.

\section{Results and Discussion}

After the necessary extractions were made, all the texts were uploaded to produce an electronic corpus of 26, 037 words, and Table 1 summarizes the two corpora.

\begin{tabular}{llll}
\hline CEAT & \multicolumn{3}{l}{ CALJA } \\
\hline Novice writers & \multicolumn{3}{l}{ Experienced writers } \\
\hline Number of texts & Number of words & Number of texts & Number of words \\
\hline 40 & 12825 & 70 & 13212 \\
\hline
\end{tabular}

Table 1. Details of the two abstract corpora

Table 2 shows that the total frequencies of evaluative that-clauses in the two corpora are about the same, with 125 in CEAT and 135 in CALJA and a frequency of 1.0 in each abstract. The current study's findings are in good consistency with those of Hyland and Tse (2005b) since the evaluative that-clause is extensively employed in scholarly prose to express the writer's opinions. It is observed that not only expert authors use the structure extensively in academic writing, but also graduate novice writers use it to convey their own views and viewpoints in academic writing.

\begin{tabular}{llll}
\hline \multicolumn{2}{l}{ CEAT } & \multicolumn{3}{l}{ CALJA } \\
\hline \multicolumn{2}{l}{ Novice writers } & \multicolumn{3}{l}{ Experienced writers } \\
\hline Frequency & Frequency /article & Frequency & Frequency /article \\
\hline 125 & 1.02 & 135 & 1.97 \\
\hline
\end{tabular}

Table 2. Frequency Distribution of Evaluative That Frequency

After calculating the overall frequencies, I checked the frequencies of that-clauses for four categories mentioned in the literature review section. 


\subsection{The evaluated entity}

The evaluation objectives of that-clause were examined, and it was determined that the evaluative that-clause is mainly employed to describe the authors' findings. In this sense, both established scholars and graduate student authors employed the evaluation. Only a few writers from both groups used evaluative that to remark on other researchers' work, and even fewer to define the study goals and methodology. As is seen in table 3,20\% clauses in novice corpus are used to describe authors' discoveries, while $25.71 \%$ in experienced group corpus. It is more likely that the novice authors were more hesitant to convey their arguments in such an assertive attitude, perhaps understanding the possible risks of accentuating their evaluations so overtly in a genre that bears such a high assessment load.

Furthermore, such an attitude is one of the defining characteristics of Turkish L2 student writers. They are reluctant to foreground their own evaluations as expert writers do. This hesitance to commit to the interactive features of academic writing has also been observed in other studies of first-person pronoun use, stance adverbs, directives, and the like (Çakır 2016; Can - Yuvayapan 2018; Çandarlı et al. 2015).

Although writers in both corpora mostly alluded to their own results, over $5 \%$ of the entities getting remark in evaluative that-clauses were about the work of others. Hyland and Jiang (2018) note that almost four quarters of all references to the others' work appear in applied linguistics as the discipline adopts an ideology that emphasizes the discursive and negotiable characteristics of argumentation.

Examples:

"The overarching finding is that context, task, and text play a significant role in language acquisition." (Novice- Evaluation of the author's own findings)

"A major challenge to implementing DA in second language (L2) classrooms is that these contexts typically do not permit ..." (Expert- Evaluation of the research methods, models, and theories)

"Previous research indicates that former schooling is an important factor in shaping teachers' beliefs about teaching..." (Novice- Evaluation of the findings of previous studies)

\begin{tabular}{llllllll}
\hline CEAT & \multicolumn{6}{l}{ CALJA } \\
\hline Novice writers & Methods & $\begin{array}{l}\text { Experienced writers } \\
\text { findings }\end{array}$ & $\begin{array}{l}\text { Other } \\
\text { scholars' } \\
\text { findings }\end{array}$ & Objectives & Methods \\
\hline $\begin{array}{l}\text { Author's } \\
\text { findings }\end{array}$ & $\begin{array}{l}\text { Other } \\
\text { scholars' } \\
\text { findings }\end{array}$ & Objectives & 25.71\% & $5.71 \%$ & $4.28 \%$ & 0 \\
\hline $20 \%$ & $5 \%$ & $2.5 \%$ & 0 & $25 \%$ & \\
\hline
\end{tabular}

Table 3. Evaluative object of evaluative that-clauses

\subsection{The evaluative stance}

The primary purpose of using evaluative that-clauses is to thematize the writer's evaluation to make it textually conspicuous by taking a stance towards the following 
proposition. Hyland and Tse (2005a, b) found that writers express their attitude by their choice of predicate while using that-clauses, which represent either attitudinal or epistemic knowledge. Attitudinal stance can be defined as either affect (dislike, expectation) or obligation (what needs to be done). After analyzing stance markers in that-clauses, it was found that, of all the that-clauses used in both corpora, the rate of that-clauses that show stance of epistemic knowledge expression is $83.4 \%$ and 81.25 $\%$ in novice and expert corpora, respectively. This is understandable because stance, in abstracts, is nearly always an epistemic evaluation, indicating the author's judgment of the plausibility. It was primarily employed to communicate the author's conviction in the trustworthiness of their discoveries (Swales 1990).

Examples:

"It is hoped that the PHRASE List will provide a basis for the systematic integration of multiword lexical items into teaching materials..." (Expert- Affect)

"It was hoped that the study would contribute to the current body of knowledge by increasing the understanding of adjustment problems faced by international dual diploma students in the United States." (Novice- Affect)

"I have demonstrated that the prevailing metaphor of transfer of skills is misleading, and that what happens is access to ..." (Expert- epistemic)

"We show that adequately organized pedagogical activity can help learners to develop their understanding of ..." (Novice- epistemic)

Although the epistemic knowledge stance marker is the most frequent marker in academic discourse, attitudinal expressions of affect and obligation are uncommon in these abstracts (Hyland - Tse, 2012). In line with the literature, expert writers used knowledge stance to express their attitudes and views in the current study. However, in the novice corpus, the evaluative that used for epistemic stance was less frequent than in the expert corpus (12.5\% and $18.5 \%$, respectively. See Table 4). Although students are usually observed to be less hesitant to use attitudinal stance in the literature, in the current study, Turkish L2 students are even less willing to employ these structures, as can be observed in Table 4. Their choice could be influenced by cultural or social discourse community in the Turkish context.

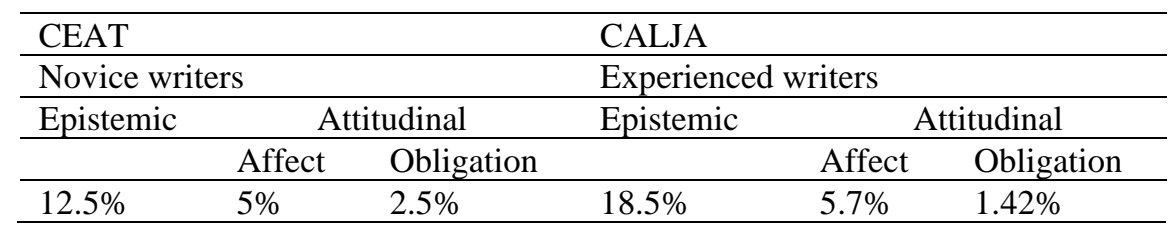

Table 4. Type of stance expressed in that-clauses

\subsection{The source of the evaluation}

Table 5 examines the occurrences of evaluative that-clauses in relation to the sources to which experienced authors and novice graduate students attribute their evaluations. Hyland - Tse (2005b) stated that writers attribute the source of evaluation 
to various sources such as human sources (writer and the other researchers), or an abstract entity like data, or the results. The current study showed that both groups frequently attributed their sources of evaluation to abstract entities such as results, findings, and the like. There were 13 and 15 propositions (see table 5) in beginner and expert corpora, respectively, with abstract sources of evaluations accounting for most of the occurrences in both corpora. In that sense, the results are consistent with the previous research in the literature (Kim - Crosthwaite 2019; Lou 2014). It can thus be noted that abstract entities operate as a source of evaluation because it is considered that it can improve the objectivity and credibility of the researchers (Swales 1990). The writers also give reference to the concealed source by either using a passive construction or an available source. The writers in both groups were less likely to hide their sources than to express them explicitly, with the hits of 1 occurrence in both corpora (see table 5).

\begin{tabular}{llllll}
\hline \multicolumn{1}{l}{ CEAT } & \multicolumn{4}{l}{ CALJA } \\
\hline \multicolumn{2}{l}{ Novice writers } & \multicolumn{4}{l}{ Experienced writers } \\
\hline Human & Abstract & Concealed & Human & Abstract & Concealed \\
\hline $5 \%$ & $32.5 \%$ & $2.5 \%$ & $18.5 \%$ & $21.5 \%$ & $1.42 \%$ \\
\hline
\end{tabular}

Table 5. Evaluative source

Examples:

"It is suggested that the capacity of humour to 'unsettle' requires careful handling." (Expert- concealed)

"The results of the study indicated that (a) Turkish students studying in... U.S.A. experience a moderate level of adjustment." (Novice- Abstract entity)

"It is suggested that the schools and educators must pay attention to this tendency, which will affect..." (Novice- concealed)

Novice writers are taught to use more abstract entities as a stance source (Hyland Tse, 2012). The relatively higher percentage of the novice groups' attribution to the abstract source of evaluation (32.5\%) than the expert groups' (21.5\%) (see table 5) exemplifies this nuance of academic writing. Furthermore, there are evident disparities in the interpersonal stance source ratios between the two corpora, with occurrences 1 in CEAT and 11 in CALJA, and with the rate of $13.75 \%$ disparity.

For example,

"I argue that the U.S. criminal justice system should accommodate NNSs of English at all proficiency levels..." (Expert- Human)

"We argue that teachers' prior assessment experience will affect their current practices ..." (Expert- Human)

Upon further exploration on the that-clauses subordinated by human sources, it was observed that the use of first-person singular ' $I$,' as the source of the findings was quite different, with the rate of $2.5 \%$ and $10 \%$, in novice and expert corpora, respectively. Of particular interest is the number of first-person plural ' $w e$ ' occurrences, none in CEAT and 6 in CALJA. However, in the literature, the use of ' $w e$ ' demonstrates the 
trustworthiness of the researchers' results by the strength of the whole discourse community (Kubotaa - Lehner 2004; Matsuda - Tardy 2006). It was thus preferred by novice authors, particularly first-person singular ' $I$ ' (Hyland 2002). Novice writers also used the plural pronoun 'they' as the human source of information. Turkish L2 novice authors' avoidance of self-mentions or other human sources for their evaluations is well documented in the literature. Can and Cang1r (2019) reported that Turkish graduate students used significantly fewer self-mention markers than their British counterparts, rendering their authorial voice. Işık-Taş (2018) investigated the role of context in establishing an authorial stance through self-mentions and concluded that while Turkish authors avoided first person singular in national journals, they presented a similar tendency to use the pronoun like other scholars while publishing in international journals. Therefore, the limited use of self-mention markers in this study can also be attributed to the prevalent writing conventions in Turkey.

\subsection{The evaluative expression}

Hyland and Tse (2005b) argued that, in their corpora, evaluative that-clauses were either verbal or non-verbal were used overwhelmingly to introduce the writer's own research or express epistemic judgments. The current study yielded similar results for the extensive use of evaluative that-clauses in verbal and non-verbal predicates. In both corpora, evaluative that-clauses headed by verb predicates account for 81.6 percent and 86.5 percent, respectively, in CEAT and CALJA. In contrast, those led by non-verb predicates account for only 19.6 percent and 14.5 percent. Hyland and Jiang (2018) suggested that published scholars in humanities increased their use of research forms within the structures of evaluative that-clauses in recent years, which is also supported by the current data.

For example,

"The research results also showed that proficiency level has a significant effect on strategy choice and use." (Expert- verbal predicate)

"-, the more important it is that they are proficient in engineering language." (Novice- Adjectival predicate)

The key finding is that all of these students accounted for the significance of their experiences studying abroad (Expert- Noun predicate)

The most frequent verbs in the expert corpus are 'suggest, indicate, show, argue, find, demonstrate.' This list of verbs overlaps with the collocates of evaluative thatclauses in applied linguistics in Hyland and Jiang's (2018) study (suggest, show, find, argue, demonstrate, p.158). According to Hyland and Jiang (2018), applied linguistics as a discipline evolving towards using items displaying greater certainty in the expressed evaluations. In the novice data, however, the list of most frequent verbs that collocate with that-clauses overlaps to some extent: suggest, advocate, indicate, show, reveal. Taşç1 and Öztürk (2021) found that reveal was frequently overused by Turkish L2 writers in a study which they compared the use of verb+that constructions in novice and expert authors' texts. This tendency may stem from the novice authors' first language, as Biber and Reppen (1998) suggested. The most frequent academic verbs in Turkish, which are görül-mekte -dir, göster-mekte-dir, bulun-muştur, görül-müss-tür, 
belirlen-miş-tir (Y1ldız - Aksan 2013), may be perceived as unveiling the facts through study, so novice Turkish authors might tend to use reveal overwhelmingly.

\begin{tabular}{lccccccccc}
\hline CEAT & \multicolumn{10}{c}{ CALJA } \\
\hline Novice writers & \multicolumn{10}{l}{ Experienced } & writers \\
\hline Non-verbal & Verbal & & Non-verbal & Verbal \\
\hline Noun Adj & $\begin{array}{c}\text { Research } \\
\text { acts }\end{array}$ & $\begin{array}{c}\text { Discourse } \\
\text { acts }\end{array}$ & $\begin{array}{c}\text { Cognitive } \\
\text { acts }\end{array}$ & Noun & Adj & Research & Discourse \\
acts & $\begin{array}{c}\text { Cognitive } \\
\text { acts }\end{array}$ \\
\hline $10 \%$ & $5 \%$ & $102.5 \%$ & $2.5 \%$ & $52.5 \%$ & $8.5 \%$ & $5.7 \%$ & $88.5 \%$ & $15.7 \%$ & $40 \%$ \\
\hline
\end{tabular}

Table 6. predicate forms in that-clauses

Although the majority of verb predicates are research verbs (reporting verbs) that express the research procedures and authors' stance, both graduate novice, and experienced writers were likely to utilize mental verb predicates leading that-clauses to convey their opinions (cognitive actions) (see table 6). Biber et al. (1999) state that cognitive verbs are essential devices to express stance since they offer some possibility like the verbs feel or assume, or a sense of certainty like find or know. In addition, the frequency of discourse verbs should also be taken into account. Discourse verbs are not utilized nearly as much in CEAT $(2.5 \%)$ as in CALJA (15.7\%). This finding overlaps with that of Wang and Chen (2012), in which the Chinese master's students did not use discourse verbs as frequently as published scholars. Novice authors may be trying to mitigate the assertiveness of their message by avoiding the discourse verbs since they advocate authors' arguments.

For example,

"They opine that the long-term goal of language learning should be ..." (NoviceCognitive act)

"I also argue that common legal terms, concepts, and texts need to find a place in the adult E.S.L. curriculum". (Expert- Cognitive act)

\section{Conclusion}

The current study used a corpus-based approach to analyze evaluative that-clauses in the abstracts of theses and dissertations of Turkish L2 graduate students writers, and also research articles' abstract by the expert authors within the discipline of applied linguistics, exploring the frequencies and various forms and functions of the structure through which authors make evaluations and built stance. In tandem with the findings of previous studies (Hyland - Tse 2005a, 2005b; Lou 2014; Wang - Chen 2012), the paper found that beginner writers fulfill the standards of academic writing while using evaluative that-clauses in their abstracts. There have been some noticeable similarities and differences between the novice and expert scholars' use of the clause. Novice authors used this feature of academic writing less frequently and hesitantly than expert authors. Published authors tend to blueprint their own and previous research findings through evaluative clauses by mainly attributing their judgments to human sources, while novice authors use abstract sources. Both groups extensively referred to verbal predicates followed by evaluative that-clauses; however, the novice authors avoided 
using discourse acts, which might be assumed another mitigation tactic to be assertive. It's conceivable that the inexperienced writers were more hesitant to express their assertions in such an evaluative manner because they were aware of the dangers of clearly stating their judgments.

Turkish graduate students showed a good command over this feature of academic writing. However, it is not clear the extent to which the students transferred the parallel structure in Turkish, $k i$ - clauses to English. We could just speculate that $\mathrm{ki}$ - clauses are used with assertive verbs or nouns, yet the students in this study avoided being assertive. There is not enough data to investigate the positive or negative influence of transfer of $k i$ - clauses on the use of evaluative that-clauses. We can also infer that the overwhelming tendency of Turkish students to draw a low authorial profile can be rooted in their first language writing conventions. In line with the Turkish academic writing conventions, Turkish novice writers avoided self-mention markers.

There are, on the other hand, some limitations of the study that need to be acknowledged. It would be rather daring to draw broad generalizations from the study presented due to relatively small corpus entries and time constraints that limited the indepth analysis. Therefore, the results should be regarded with caution. It is necessary to conduct a more longitudinal study based on a larger corpus to explore the extensive use of evaluative that-clauses. A longitudinal study could reveal more rare uses and specific attitudinal tendencies in the use of evaluative that-clauses.

\section{References}

Aikhenvald, A. I. U. (2018). The Oxford handbook of evidentiality. Oxford: Oxford University Press.

AKsu-Koç, A. (2016). "The interface of evidentials and epistemics in Turkish". Exploring the Turkish Landscape: Essays in honor of Eser Erguvanli-Taylan (Edt.: M. Güven, D. Akar., B. Öztürk, M. Kelepir ). Amsterdam: John Benjamins, 143-156

Arslan, S.; De KoK, D.; BastiaAnSE, R. (2017). "Processing grammatical evidentiality and time reference in Turkish heritage and monolingual speakers". Bilingualism (Cambridge, England), 20(3), 457-472.

BIBER, D. (2006). University language: A corpus-based study of spoken and written registers. Amsterdam: John Benjamins Publishing.

Biber, D.; FInEgan, E. (1988). "Adverbial stance types in English". Discourse Processes, 11:1-34.

BIBER, D.; FinEGAN, E. (1989). "Styles of stance in English: Lexical and grammatical marking of evidentiality and affect". Text - Interdisciplinary Journal for the Study of Discourse, 9/1: 93-124.

BIBER, D. et al. (1999). Longman grammar of spoken and written English. Harlow: Longman.

BIBER, D.; REPPEN, R. (1998). "Comparing native and learner perspectives on English grammar: A study of complement clauses". Learner English on computer (Edt.: S. Granger). Harlow: Longman.

ÇAKIR, H. (2016). "Native and non-native writers' use of stance adverbs in English research article abstracts". Open Journal of Modern Linguistics, 6/2: 85-96.

CAN, C.; YuvaYAPAN, F. (2018). "Stance-taking through metadiscourse in doctoral dissertations 1. International Journal of Languages' Education and Teaching". International Journal of Languages' Education and Teaching, 6/1: 128-142.

CAN, T.; CANGIR, H. (2019). "A corpus-assisted comparative analysis of self-mention markers in doctoral dissertations of literary studies written in Turkey and the UK". Journal of English for academic purposes, 42: 1-14. 
ÇANDARLI, D. (2012). "A Cross-Cultural Investigation of English and Turkish Research Article Abstracts in Educational Sciences". Kalbu studijos, 20/20: 12-17.

ÇANDARLI, D.; BAYYURT, Y.; MARTI, L. (2015). "Authorial presence in L1 and L2 novice academic writing: Cross-linguistic and cross-cultural perspectives". Journal of English for academic purposes, 20: 192-202.

CHAFE, W. L. (1986). "Evidentiality in English conversation and academic writing". Evidentiality: TheLinguistic Coding of Epistemology (Edt.: W.L. Chafe; J. Nichols). N.J.:Ablex: Norwood, 261-272.

Charles, M. (2006). "The Construction of Stance in Reporting Clauses: A Cross-disciplinary Study of Theses". Applied Linguistics, 27/3: 492-518.

ChARLES, M. (2007). "Argument or evidence? disciplinary variation in the use of the noun that pattern in stance construction". English for Specific Purposes, 26/2: 203-218.

Diewald, G.; SMirnova, E. (2010). Linguistic realization of evidentiality in European languages. Berlin-New York: De Gruyter Mouton.

GENÇER BALOĞLU, Z. (2020). Japonca ve Türkçede Görünüş (Aspekt): Eski Türkçe ve Hakasça ile Mukayeseli. Ankara: Türk Dil Kurumu.

GöKSEL, A.; KeRSLAKE, C. (2005). Turkish: A comprehensive grammar. Germany: Routledge.

HERRIMAN, J. (2000). "The functions of extraposition in English texts". Functions of Language, 7/2: 203-230.

Hewings, M.; Hewings, A. (2002). "“It is interesting to note that...": a comparative study of anticipatory 'it' in student and published writing". English for specific purposes (New York, N.Y.), 21/4: 367-383.

Hunston, S. (2000). "Evaluation and the planes of discourse: Status and value in persuasive texts". Evaluation in Text: Authorial Stance and the Construction of Discourse (Edt.: S. Hunston; G. Thompson). Oxford: Oxford University Press.

Hunston, S., - Thompson, G. (2001). Evaluation in Text: Authorial Stance and the Construction of Discourse (New Edition ed.). Place of publication not identified: Oxford University Press Incorporated.

HYLAND, K. (2002). "Authority and invisibility: authorial identity in academic writing. Journal of Pragmatics, 34: 1091-1112.

Hyland, K. (2005). "Stance and engagement: a model of interaction in academic discourse". Discourse Studies, 7/2: 173-192.

Hyland, K., - JiAnG, F. K. (2018). "We Believe That ... ': Changes in an Academic Stance Marker" Australian Journal of Linguistics, 38/2: 139-161.

Hyland, K., - TSE, P. (2005a). "Evaluative that constructions: signalling stance in research abstracts'". Functions of Language, 12/1: 39-63.

HYLAND, K., - TSE, P. (2005b). "Hooking the reader: a corpus study of evaluative that in abstracts". English for specific purposes (New York, N.Y.), 24/2: 123-139.

HyLAND, K., - TSE, P. (2012). "'She has received many honours': Identity construction in article bio statements". Journal of English for academic purposes, 11/2: 155-165.

IŞIK-TAŞ, E. E. (2018). "Authorial identity in Turkish language and English language research articles in Sociology: The role of publication context in academic writers' discourse choices". English for specific purposes (New York, N.Y.), 49: 26-38.

JiAnG, F.; Hyland, K. (2015). "'The fact that': Stance nouns in disciplinary writing". Discourse Studies, 17/5: 529-550.

KesicI, E. (2013). "Ki- Clauses in Turkish" Coyote Papers, University of Arizona Linguistics Circle (Tucson, Arizona), 21.

Kim, C.; Crosthwaite, P. (2019). "Disciplinary differences in the use of evaluative that: Expression of stance via that-clauses in business and medicine". Journal of English for academic purposes, 41: $1-14$.

KubotaA, R.; Lehner, A. (2004). "Toward critical contrastive rhetoric". Journal of Second Language Writing, 13: 7-27. 
Lou, B. (2014). "A Corpus-Based Study of Evaluative That-Clause in Abstracts of Chinese Learners' Doctoral Dissertations". International journal of computer-assisted language learning and teaching, 4/3: 68-79.

MATSUDA, P. K.; TARDY, C. M. (2006). "Voice in academic writing: The rhetorical construction of author identity in blind manuscript review". English for Specific Purposes, 26/3: 235-249.

OCHS, E.; SCHIEFFELIN, B. (1989). Language has a heart. Text - Interdisciplinary Journal for the Study of Discourse, 9/1: 7-26.

Swales, J. (1990). Genre analysis: English in academic and research settings. Cambridge: Cambridge University Press.

SwALES, J. (2002). "Integrated and fragmented worlds: EAP materials and corpus linguistics". Academic discourse (Edt.: J. Flowerdew). Harlow: Pearson, 150-164.

TARONE, E. et al. (1998). "On the use of the passive and active voice in astrophysics journal papers: With extensions to other languages and other fields". English for Specific Purposes, 17: 113-132.

TAŞÇI, S.; ÖZTÜRK, Y. (2021). "Post-predicate that-caluses controlled by verbs in native and nonnative academic writing: A corpus-based study". Australian Journal of Linguistics, 4/1: 18-33.

ThOMPSON, G.; Ye, Y. (1991). "Evaluation in the reporting verbs used in academic papers". Applied Linguistics, 12/4: 365-382.

WANG, Y.; CHEN, H. (2012). "The stance study of evaluative that clauses in English abstracts of Chinese master theses" International Journal of English Linguistics, 2/5: 11-17.

Wu, S. (1995). Transfer in Chinese students' academic English writing. ProQuest Dissertations.

YANG, W.; NARROG, H. (2018). Evidentiality in Japanese. Oxford: Oxford University Press.

YILDIZ, İ.; AKSAN, M. (2014). "Türkçe bilimsel metinlerde eylemler: Derlem temelli bir inceleme". 27. Ulusal Dilbilim Kurultayı Bildirileri. Ankara: Hacettepe Üniversitesi, 247-253. 